\title{
Unveiling the Structure and Composition of Titanium Oxide Nanotubes through Ion Exchange Chemical Reactions and Thermal Decomposition Processes
}

\author{
Odair P. Ferreira, ${ }^{a}$ Antônio G. Souza Filho, ${ }^{b}$ Josué Mendes Filho ${ }^{b}$ and Oswaldo L. Alves ${ }^{*, a}$ \\ ${ }^{a}$ Instituto de Química, Universidade Estadual de Campinas, CP 6154, 13084-862 Campinas-SP, Brazil \\ ${ }^{b}$ Departamento de Física, Universidade Federal do Ceará, CP 6030, 60455-900 Fortaleza-CE, Brazil
}

Neste trabalho reportamos reações de troca iônica e decomposição térmica em nanotubos de óxido de titânio, obtidos pelo tratamento hidrotérmico de $\mathrm{TiO}_{2}$ e $\mathrm{NaOH}$. Considerando os resultados obtidos, sugerimos uma nova composição química para os nanotubos: $\mathrm{Na}_{2} \mathrm{Ti}_{3} \mathrm{O}_{7} \cdot \mathrm{nH}_{2} \mathrm{O}$. Os resultados também indicam que a estrutura da parede dos nanotubos seria isoestrutural às lamelas observadas para o $\mathrm{Na}_{2} \mathrm{Ti}_{3} \mathrm{O}_{7}$ bulk. Dependendo da natureza da lavagem (água deionizada ou solução ácida) executada no nanotubo após o tratamento hidrotérmico a concentração de íons $\mathrm{Na}^{+}$pode ser modificada através de um processo de troca iônica do $\mathrm{Na}^{+}$por $\mathrm{H}^{+}$. Tais resultados permitem sugerir a seguinte fórmula química geral para os nanotubos obtidos: $\mathrm{Na}_{2-\mathrm{x}} \mathrm{H}_{\mathrm{x}} \mathrm{Ti}_{3} \mathrm{O}_{7} \cdot \mathrm{nH}_{2} \mathrm{O}(0 \leq x \leq 2)$, sendo $\mathrm{x}$ dependente das condições de lavagens.

In this paper we report the ion exchange reactions and the thermal decomposition of titanium oxide nanotubes, obtained by hydrothermal treatment of $\mathrm{TiO}_{2}$ and $\mathrm{NaOH}$. Based on these results we propose a new composition for the as-prepared nanotubes as $\mathrm{Na}_{2} \mathrm{Ti}_{3} \mathrm{O}_{7} \cdot \mathrm{nH}_{2} \mathrm{O}$. Our results also suggest that nanotube walls have structure similar to those observed in the layer of the bulk $\mathrm{Na}_{2} \mathrm{Ti}_{3} \mathrm{O}_{7}$. Depending on how the washing process is performed on the nanotubes (water or acid solutions) the $\mathrm{Na}^{+}$content can be modified via the exchange reaction of $\mathrm{Na}^{+}$by $\mathrm{H}^{+}$. Thus, a general chemical formula was also proposed: $\mathrm{Na}_{2-\mathrm{x}} \mathrm{H}_{\mathrm{x}} \mathrm{Ti}_{3} \mathrm{O}_{7} \cdot \mathrm{nH}_{2} \mathrm{O}(0 \leq x \leq 2)$, $\mathrm{x}$ being dependent on the washing process.

Keywords: titanate nanotubes, nanorods, $\mathrm{TiO}_{2}$, photocatalysis, hydrothermal treatment

\section{Introduction}

The discovery of carbon nanotubes in early 90's opened a new research area in materials science. ${ }^{1}$ Since then, much attention has been given to the study and search for new materials with tubular structures. The understanding of nanotube formation mechanisms has significantly improved but a clear picture of this process is still an open subject. Since carbon nanotubes originate from graphite layers (graphene) a lot of effort has been devoted to prepare nanotubes from other layered materials. After carbon nanotubes the first studied inorganic nanotubes were $\mathrm{WS}_{2}$, $\mathrm{MoS}_{2}, \mathrm{BN}$ and $\mathrm{NbS}_{2}{ }^{2-5}$ The preparation of these nanotubes from layered materials leads to the thought that is possible to prepare nanotubes from all materials whose bulk counterpart is a layered compound. Nowadays, a considerable list of inorganic nanotubes is known and it is

* e-mail: oalves@iqm.unicamp.br increasing at an amazing rate. Among the inorganic nanotubes, titanium oxide nanotubes are very attractive because these nanostructures are promising for applications as photocatalysts, UV absorbers, dye-sensitizing solar cells, self-cleaning devices, and catalyst supports. ${ }^{6,7}$

Kasuga et al. ${ }^{8}$ reported the preparation of titanium oxide nanotubes through hydrothermal treatment of $\mathrm{TiO}_{2}-\mathrm{SiO}_{2}$ powders in aqueous $\mathrm{NaOH}$ solutions. This preparation method is very simple and inexpensive. However, a great debate has been established in the literature regarding the formation mechanism, composition and atomic structure of the titanium oxide nanotubes obtained by the Kasuga method. ${ }^{9-13}$ The consensus point about the formation mechanism is that the titanium oxide nanotubes are scrolllike tubes being formed by rolling up the layers originating from a layered precursor obtained during the hydrothermal treatment. Some reports propose that compounds with lamellar structure can be transformed into nanotubes or nanorods once a driving force for this mechanism would be activated. ${ }^{14-16}$ 
The composition and structure of the titanium oxide nanotubes is also debated. In the pioneer work of Kasuga et al. ${ }^{8}$ they assume the composition as being anatase $\mathrm{TiO}_{2}$, a proposal that was also reinforced by others researchers. ${ }^{10}$ Peng's group has proposed that the nanotube walls present $\mathrm{H}_{2} \mathrm{Ti}_{3} \mathrm{O}_{7}$-like structure/composition. ${ }^{11,13,17,18}$ More complex structures such as $\mathrm{H}_{2} \mathrm{Ti}_{3} \mathrm{O}_{7} \cdot \mathrm{nH}_{2} \mathrm{O},{ }^{19} \mathrm{Na}_{\mathrm{x}} \mathrm{H}_{2-\mathrm{x}} \mathrm{Ti}_{3} \mathrm{O}_{7},{ }^{20}$ $\mathrm{Na}_{2} \mathrm{Ti}_{2} \mathrm{O}_{4}(\mathrm{OH})_{2},{ }^{21} \mathrm{H}_{0.7} \mathrm{Ti}_{1.825} \square_{0.175} \mathrm{O}_{4.0} \cdot \mathrm{H}_{2} \mathrm{O}(\square=$ vacancy $),{ }^{22,23}$ and $\mathrm{Na}_{2} \mathrm{Ti}_{2} \mathrm{O}_{5} \cdot \mathrm{H}_{2} \mathrm{O},{ }^{24}$ have also been suggested.

The detailed understanding of the structure and composition of these nanostructures is a key point in order to tailor the chemical properties for a given application. In this work we focus our study in the composition and structure of titanium oxide nanotubes prepared by the Kasuga method. Based on results obtained from ion exchange reactions and thermal decomposition processes we propose a new composition for these titanium oxide nanotubes$\mathrm{Na}_{2} \mathrm{Ti}_{3} \mathrm{O}_{7} \cdot \mathrm{nH}_{2} \mathrm{O}$. From the structural point view, the nanotube walls have structure similar to those observed in layer of the bulk $\mathrm{Na}_{2} \mathrm{Ti}_{3} \mathrm{O}_{7}$. Since the $\mathrm{Na}$ content in the titanate nanotube changes depending on the nature (water or acid solution) and time of washing we propose that the general chemical formula for the titanate nanotubes obtained through Kasuga's method is $\mathrm{Na}_{2-\mathrm{x}} \mathrm{H}_{\mathrm{x}} \mathrm{Ti}_{3} \mathrm{O}_{7} \cdot \mathrm{nH}_{2} \mathrm{O}(0 \leq x \leq 2)$. Additionally, by analyzing the products of the thermal decomposition process it was possible to get a relationship between the structure and morphology of the treated nanotubes.

\section{Experimental}

All chemicals (reagent grade, Aldrich, Merck or Baker's Analyzed) were used as received, without further purification processes. All solutions were prepared with deionized water.

\section{Titanium oxide nanotube preparation}

$2.00 \mathrm{~g}$ (25.0 mmol) of $\mathrm{TiO}_{2}$ (anatase) were suspended in $60 \mathrm{~mL}$ of $10 \mathrm{~mol} \mathrm{~L}^{-1}$ aqueous $\mathrm{NaOH}$ solution for $30 \mathrm{~min}$. The white suspension formed was transferred to a $90 \mathrm{~mL}$ Teflon-lined stainless steel autoclave and kept at $170 \pm 5{ }^{\circ} \mathrm{C}$ for $170 \mathrm{~h}$. After cooling to room temperature, the resulting white solid was divided into two parts: $(i)$ one was washed several times with deionized water until $\mathrm{pH}$ 11-12 (hereafter $\mathrm{NTTiO}_{\mathrm{x}}$ ) and (ii) the other was washed with $0.1 \mathrm{~mol} \mathrm{~L}^{-1}$ aqueous $\mathrm{HCl}$ solution until $\mathrm{pH}$ 3-4 (hereafter $\mathrm{HCl}-\mathrm{NTTiO}_{\mathrm{x}}$ ). Afterwards, both samples were dried at $60 \pm 5{ }^{\circ} \mathrm{C}$ for $24 \mathrm{~h}$.

Ion exchange reaction: $\mathrm{H}^{+}, \mathrm{Cu}^{2+}, \mathrm{Co}^{2+}, \mathrm{Ca}^{2+}$

The $\mathrm{H}^{+}$-exchange reaction and $\mathrm{M}^{2+}$-exchange reactions $\left(\mathrm{M}^{2+}=\mathrm{Cu}^{2+}, \mathrm{Co}^{2+}\right.$ and $\left.\mathrm{Ca}^{2+}\right)$ in the nanotubes were carried out by slightly different procedures. Proton-exchange was carried out by suspending $100 \mathrm{mg}$ of $\mathrm{NTTiO}_{\mathrm{x}}$ in $50 \mathrm{~mL}$ of $0.1 \mathrm{~mol} \mathrm{~L}^{-1} \mathrm{HCl}$ at room temperature for $24 \mathrm{~h}$ (hereafter $\left.\mathrm{H}-\mathrm{NTTiO}_{\mathrm{x}}\right)$. Metal $\left(\mathrm{Cu}^{2+}, \mathrm{Co}^{2+}\right.$ and $\left.\mathrm{Ca}^{2+}\right)$ ion exchange reactions were carried out by suspending $100 \mathrm{mg}$ of $\mathrm{NTTiO}_{x}$ in $100 \mathrm{~mL}$ of $0.05 \mathrm{~mol} \mathrm{~L}^{-1}$ of the corresponding aqueous solutions of the metal nitrate or chloride at room temperature for $24 \mathrm{~h}$ (hereafter $\mathrm{Cu}, \mathrm{Co}, \mathrm{Ca}-\mathrm{NTTiO}_{\mathrm{x}}$ ). All solid products were isolated by centrifugation, washed several times with deionized water and dried under vacuum.

\section{Thermal treatment of the nanotubes}

As-prepared nanotubes $\left(\mathrm{NTTiO}_{\mathrm{x}}\right)$ and protonexchanged nanotubes $\left(\mathrm{H}-\mathrm{NTTiO}_{\mathrm{x}}\right)$ were thermally treated in the $25-900{ }^{\circ} \mathrm{C}$ temperature range using a tubular furnace (Barnstead/Thermolyne, model 21130). All samples were heated in static air at $10{ }^{\circ} \mathrm{C}$ min $^{-1}$ and kept at a given temperature for $1 \mathrm{~h}$.

\section{Characterization}

Transmission electron microscope (TEM) images were obtained using a Carl Zeiss CEM-902 microscope (80 kV). The TEM samples were prepared by dropping a water suspension of sample powders on a parlodion coated copper grid and letting the water evaporate at room temperature. Spectra of energy dispersive x-ray spectroscopy (EDS) were collected using a Noran System SIX (Thermo Electron Corporation, model 6714A-1SUS-SN) probe attached to the scanning electron microscope, JEOL 6360LV. X-ray diffraction (XRD) measurements were performed on a Shimadzu XRD6000 diffractometer using $\operatorname{CuK} \alpha(\lambda=$ $1.5406 \AA$ ) radiation and operating with $30 \mathrm{~mA}$ and $40 \mathrm{kV}$. A scan rate of $1^{\circ} \mathrm{min}^{-1}$ was employed. In situ XRD measurements were carried out in the $25-900{ }^{\circ} \mathrm{C}$ temperature range using a high temperature furnace (HA1001, Shimadzu) attached to a Shimadzu XRD6000 diffractometer. The heating rate was $10{ }^{\circ} \mathrm{C} \mathrm{min}^{-1}$ and before each measurement an interval of $15 \mathrm{~min}$ was used for stabilizing the temperature. Specific surface area was measured by nitrogen adsorption-desorption in a Flowsorb 2300 equipment (Micrometrics Instrument Corp.), using the BET method. FTIR spectra were obtained on a Bomen FTLA2000 spectrometer using "Fluorolube" (4000-1300 $\mathrm{cm}^{-1}$ ) or "Nujol" (1300-250 $\left.\mathrm{cm}^{-1}\right)$ mulls between CsI windows, with $4 \mathrm{~cm}^{-1}$ resolution for 128 scans. DTA-TGA analyses were carried out using a TA equipment, model SDT Q600 over the $25-1000{ }^{\circ} \mathrm{C}$ temperature range with a heating rate of $10{ }^{\circ} \mathrm{C} \mathrm{min}-1$ under an air flow of $100 \mathrm{~mL}$ $\min ^{-1}$. 


\section{Results and Discussion}

\section{Structure and composition of the nanotubes}

Figure 1 shows a low magnification TEM image of the as-prepared titanium oxide nanotubes produced by alkali hydrothermal treatment of anatase $\mathrm{TiO}_{2}$ powder. The nanotubes are multi-walled with an average outer (inner) diameter of approximately $9 \mathrm{~nm}(5 \mathrm{~nm})$ and a length of several tens of $\mathrm{nm}$. The nanotubes are opened at both ends and show a uniform diameter distribution (inset to Figure 1).

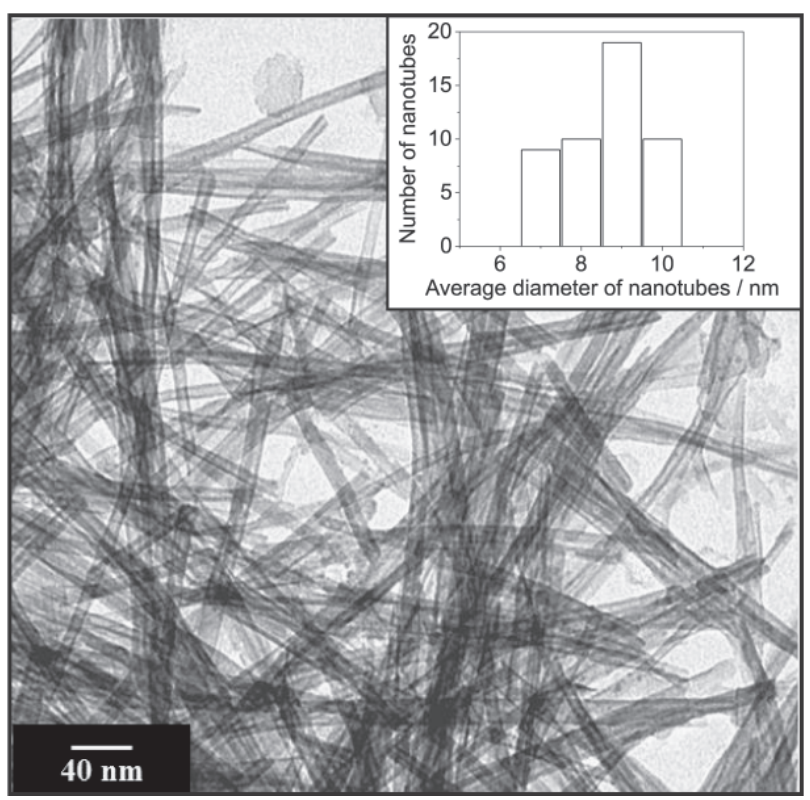

Figure 1. TEM images of titanium oxide nanotubes prepared through the hydrothermal treatment of anatase $\mathrm{TiO}_{2}$ in $\mathrm{NaOH}$ solution. The inset is a distribution of the average external diameter.

We observed a large increase of the specific surface area of the powders after the hydrothermal treatment. The final products (nanotubes) present a specific surface area of $128 \mathrm{~m}^{2} \mathrm{~g}^{-1}$ being much larger than that of the precursor $\mathrm{TiO}_{2}\left(7 \mathrm{~m}^{2} \mathrm{~g}^{-1}\right)$. This large enhancement in the surface area is attributed to the tubular morphology where additional porous (nanotube core and intertube spacing) are formed. ${ }^{25}$

The chemical composition of the nanotubes was studied by EDS. Figure $2 \mathrm{a}$ and $2 \mathrm{~b}$ show a typical EDS spectrum of $\mathrm{NTTiO}_{x}$ and $\mathrm{HCl}-\mathrm{NTTiO}_{x}$, respectively. The results clearly indicate the presence of $\mathrm{Na}$, $\mathrm{Ti}$ and $\mathrm{O}$ peaks for both $\mathrm{NTTiO}_{x}$ and HCl-NTTiO $\mathrm{N}_{\mathrm{x}}$ samples. The unassigned peak in Figure $2 \mathrm{a}$ and $2 \mathrm{~b}$ represents $\mathrm{C}$ coming from the sample support (graphite) and is also due to the carbon deposited on the sample surface to increase its conductivity. For samples washed with $\mathrm{HCl}$ solution, we could observe the presence of $\mathrm{Cl}$ (Figure 2). It is adsorbed in the surface of agglomerates. This is reasonable since
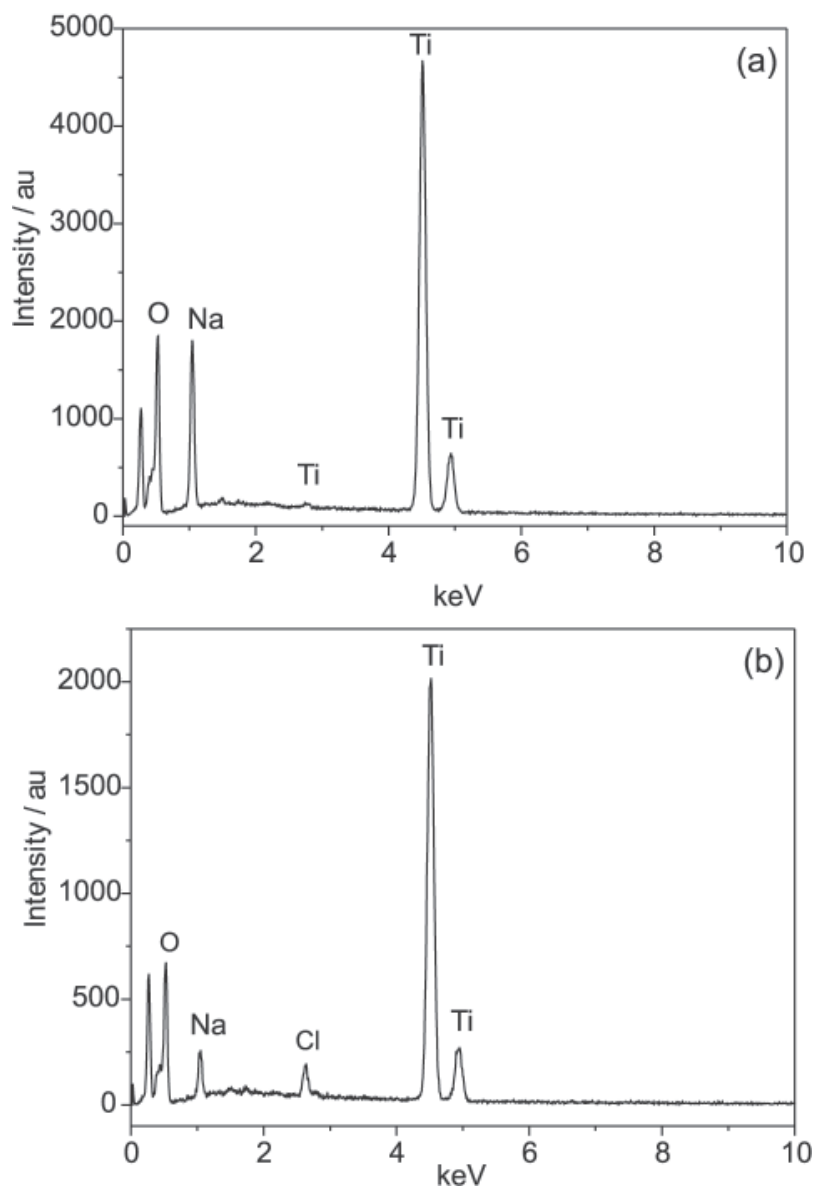

Figure 2. EDS spectra obtained from (a) nanotubes washed with deionized water $\left(\mathrm{NTTiO}_{\mathrm{x}}\right)$ and (b) aqueous $\mathrm{HCl}$ solution $\left(\mathrm{HCl}-\mathrm{NTTiO}_{\mathrm{x}}\right)$.

the $\mathrm{HCl}$ washed nanotube samples were not subsequently washed with deionized water.

The present of $\mathrm{Na}^{+}$ions in both samples should be associated with two phenomena: $(i) \mathrm{Na}^{+}$adsorbed on the tube surface and/or (ii) structural $\mathrm{Na}^{+}$(in this case the cations belong to the nanotube structure). In Table 1 are listed the $\mathrm{Na} / \mathrm{Ti}$ ratios obtained from EDS analyses. The $\mathrm{Na} / \mathrm{Ti}$ ratio for $\mathrm{NTTiO}_{\mathrm{x}}(0.67)$ is larger than that of $\mathrm{HCl}-$ $\mathrm{NTTiO}_{x}(0.20)$, thereby indicating that the nanotube chemical composition strongly dependents on the washing conditions. The $\mathrm{Na} / \mathrm{Ti}=0.67$ ratio is similar to that observed in the lamellar $\mathrm{Na}_{2} \mathrm{Ti}_{3} \mathrm{O}_{7}$ (sodium titanate) compound. ${ }^{26}$ Our analysis indicates that the composition of the nanotubes washed with deionized water is close to $\mathrm{Na}_{2} \mathrm{Ti}_{3} \mathrm{O}_{7}$. Therefore, we propose that the $\mathrm{Na}$ belongs to the nanotube structure, as we discuss below.

In Figure 3 we show the X-ray diffratograms of the asprepared nanotubes (curves $b$ and c), which are significantly different from the structure of the precursor anatase $\mathrm{TiO}_{2}$ (curve a). The broad and overlapped peaks are attributed to the curvature effect on the atomic layers to form the nanotube. A precise assignment to any titanium oxide and titanate phase 
Table 1. $\mathrm{Na} / \mathrm{Ti}$ and $\mathrm{M} / \mathrm{Ti}(\mathrm{M}=\mathrm{Cu}, \mathrm{Co}, \mathrm{Ca})$ ratios of the as-prepared and modified nanotubes using ion exchange reactions

\begin{tabular}{lcc}
\hline Sample & $\mathrm{Na} / \mathrm{Ti}$ & $\mathrm{M} / \mathrm{Ti}(\mathrm{M}=\mathrm{Cu}, \mathrm{Co}, \mathrm{Ca})$ \\
\hline NTTiO $_{\mathrm{x}}$ & 0.67 & - \\
HCl-NTTiO $_{x}$ & 0.20 & - \\
H-NTTiO $_{\mathrm{x}}$ & 0.00 & - \\
Cu-NTTiO $_{x}$ & 0.013 & 0.23 \\
Co-NTTiO $_{x}$ & 0.013 & 0.23 \\
Ca-NTTiO $_{x}$ & 0.050 & 0.20 \\
\hline
\end{tabular}

considering the observed diffracted peaks is somewhat difficult. However, the X-ray diffractograms are typical of layered materials, which suggest that the nanotubes are multiwalled. The presence of $\mathrm{Na}^{+}$in the samples and the profile of the diffraction peaks suggest that the nanotubes are formed by a titanate phase similar to the vanadium oxide nanotubes that are formed by vanadate. ${ }^{27,28}$

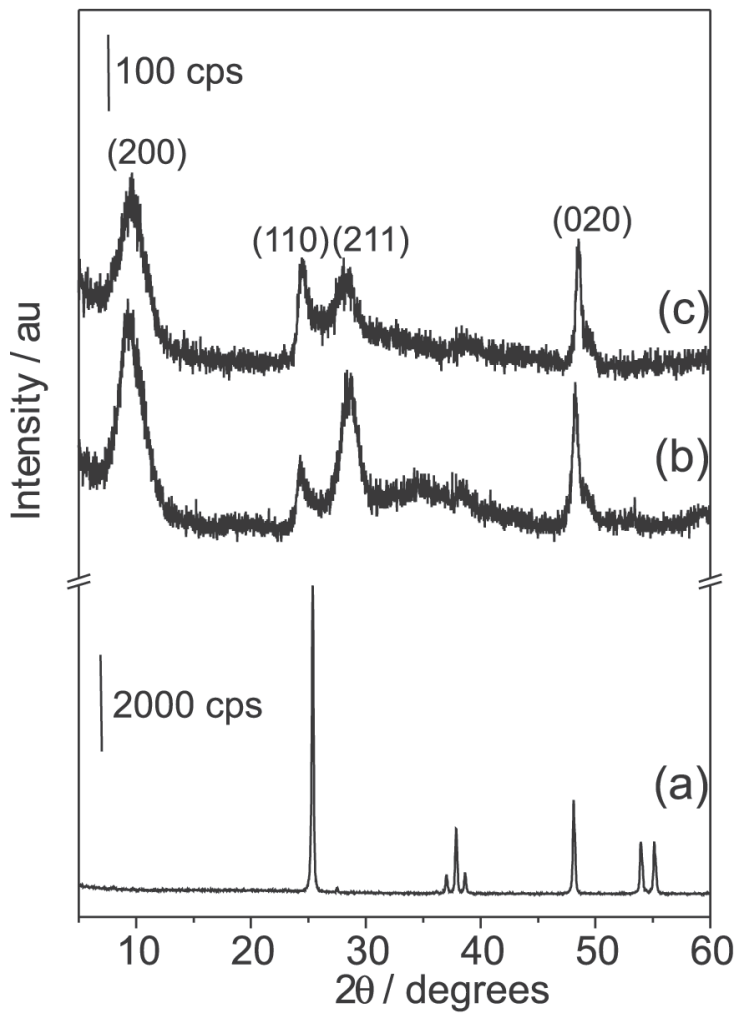

Figure 3. X-ray patterns of (a) anatase $\mathrm{TiO}_{2}$ and titanium oxide nanotubes (b) washed with deionized water and (c) aqueous $\mathrm{HCl}$ solution.

Chen et al. ${ }^{18}$ suggested that the nanotubes obtained through hydrothermal treatment of $\mathrm{TiO}_{2}$ and $\mathrm{NaOH}$ have walls formed by $\mathrm{Ti}_{3} \mathrm{O}_{7}^{2-}$ (titanate) and the interlamellar region would be occupied by $\mathrm{H}^{+}$ions, thus forming nanotubes with the composition $\mathrm{H}_{2} \mathrm{Ti}_{3} \mathrm{O}_{7}$, with a monoclinic unit cell. Our crystallographic data are similar to those observed by Chen et al. ${ }^{18}$ and the peak assignment was performed based on their work. However, the EDS analysis of our samples washed with water indicates the presence of $\mathrm{Na}^{+}$, thus suggesting that the composition is closer to that of $\mathrm{Na}_{2} \mathrm{Ti}_{3} \mathrm{O}_{7}$. The presence of $\mathrm{Na}^{+}$is due to the high alkalinity of the enviromment where the nanotubes are formed. The structures of $\mathrm{H}_{2} \mathrm{Ti}_{3} \mathrm{O}_{7}$ and $\mathrm{Na}_{2} \mathrm{Ti}_{3} \mathrm{O}_{7}$ lamellar compounds are very close to one other, differing only in the position of $\mathrm{H}^{+}$and $\mathrm{Na}^{+}$in the interlamelar space. ${ }^{13}$ Thus, when the material was washed with $\mathrm{HCl}$, the $\mathrm{Na} / \mathrm{Ti}$ ratio decreases due to the cation exchange of $\mathrm{Na}^{+}$by $\mathrm{H}^{+}$and the nanotube composition is appropriately described by a $\mathrm{Na}_{2-x} \mathrm{H}_{x} \mathrm{Ti}_{3} \mathrm{O}_{7}$ chemical formula. The $x$ value changes from zero to two depending on how the washing process is performed. The ion exchange of $\mathrm{Na}^{+}$by $\mathrm{H}^{+}$in bulk titanates is a well-known mechanism reported in the literature and it should be somewhat similar in titanate nanotubes. ${ }^{29}$ The FTIR, TGA and in situ XRD measurements also indicated the presence of water molecules in the interlayer regions. Therefore, the chemical formula for the titanate nanotubes obtained by the Kasuga method would be better described as $\mathrm{Na}_{2-\mathrm{x}} \mathrm{H}_{\mathrm{x}} \mathrm{Ti}_{3} \mathrm{O}_{7} \cdot \mathrm{nH}_{2} \mathrm{O}(0 \leq x \leq 2)$.

\section{Ion exchange reactions}

In order to give further support to the assumption that nanotube walls are formed by titanate and that $\mathrm{Na}^{+}$belongs to nanotubes structure, we have submitted the $\mathrm{Na}^{+}$enriched nanotubes $\left(\mathrm{NTTiO}_{\mathrm{x}}\right)$ to ion exchange reactions replacing $\mathrm{Na}^{+}$by $\mathrm{H}^{+}, \mathrm{Cu}^{2+}, \mathrm{Ca}^{2+}$ and $\mathrm{Co}^{2+}$ cations. These ion exchange reactions in bulk titanates are well-known in the literature. ${ }^{29-31}$ We also used these reactions to get information about the interlayer space of titanate nanotubes. Furthermore, such reactions can be used to chemically modify these inorganic nanotubes. ${ }^{32}$

EDS analyses were employed for evaluating the chemical composition after the exchange chemical reactions. Table 1 shows the $\mathrm{Na} / \mathrm{Ti}$ and $\mathrm{M} / \mathrm{Ti}\left(\mathrm{M}=\mathrm{Cu}^{2+}\right.$, $\mathrm{Ca}^{2+} \mathrm{e} \mathrm{Co}^{2+}$ ) ratios for modified nanotubes. We observed that the $\mathrm{H}^{+}$-exchanged nanotubes $\left(\mathrm{H}-\mathrm{NTTiO}_{\mathrm{x}}\right)$ present only $\mathrm{Ti}$ and $\mathrm{O}$. The hydrogen atom is very light and can not be detected by the probe. The absence of $\mathrm{Na}^{+}$ions in this sample indicates that the exchange of $\mathrm{Na}^{+}$by $\mathrm{H}^{+}$was complete or, at least, the remaining $\mathrm{Na}^{+}$concentration is below the detection threshold of the probe. These results of chemical analyses suggest that after the ion exchange the new composition of the nanotube would be close to $\mathrm{H}_{2} \mathrm{Ti}_{3} \mathrm{O}_{7} \cdot \mathrm{nH}_{2} \mathrm{O}$ (supported by TGA experiments). On the other hand, the ion exchange was not complete for the $\mathrm{M}^{2+}$ cations, where a small amount of $\mathrm{Na}^{+}$was observed as shown in Table 1. By summing up the positive charges coming from $\mathrm{M}^{2+}$ and from remaining sodium, we verify that the total charge is not enough to compensate the negative charge of titanate $\left(\mathrm{Ti}_{3} \mathrm{O}_{7}^{2-}\right)$. Thus, we suggest that 
$\mathrm{H}^{+}$(a light element not detected by EDS) also belongs to the atomic composition, since the solutions used for ion exchange reactions are either acidic or slightly acidic. Therefore, the composition of these nanotubes should be close to $\left(\mathrm{Na}_{1-\mathrm{x}} \mathrm{H}_{\mathrm{x}}\right)_{2-2 \mathrm{y}} \mathrm{M}_{\mathrm{y}} \mathrm{Ti}_{3} \mathrm{O}_{7} \cdot \mathrm{nH}_{2} \mathrm{O}$. The ion exchange observed for cations $\mathrm{M}^{2+}$ correspond to $70 \%$ of total exchange capacity of the nanotubes. Similar results were observed by Ma $e t$ al. $^{33}$ when they analyzed the exchange properties of titanium oxide nanotubes with alkaline metals.

The nanotube structure is preserved after ion exchange as can be seen in the X-ray patterns (Figure 4). ${ }^{20}$ The interlayer distance for ion exchanged nanotubes is slightly modified when compared with the as-prepared $\mathrm{NTTiO}_{x}$ $(0.9 \mathrm{~nm})$. The largest variation was observed for $\mathrm{Co}^{2+}-$ exchanged nanotubes for which the interlayer distance increases by approximately $0.1 \mathrm{~nm}$. The distance was obtained by considering the diffracted peak close to $2 \theta \sim$ $10^{\circ}$. The profile of this peak is broad and asymmetric and suggests that the chemical environment between the layers is disordered. We also observed changes in the relative intensity of the peaks above $2 \theta=25^{\circ}$. Such variations could be associated with different lattice distortions induced by the different cations, thus indicating that the exchanged cations were incorporated into the lattice rather than only adsorbed in the external surface.

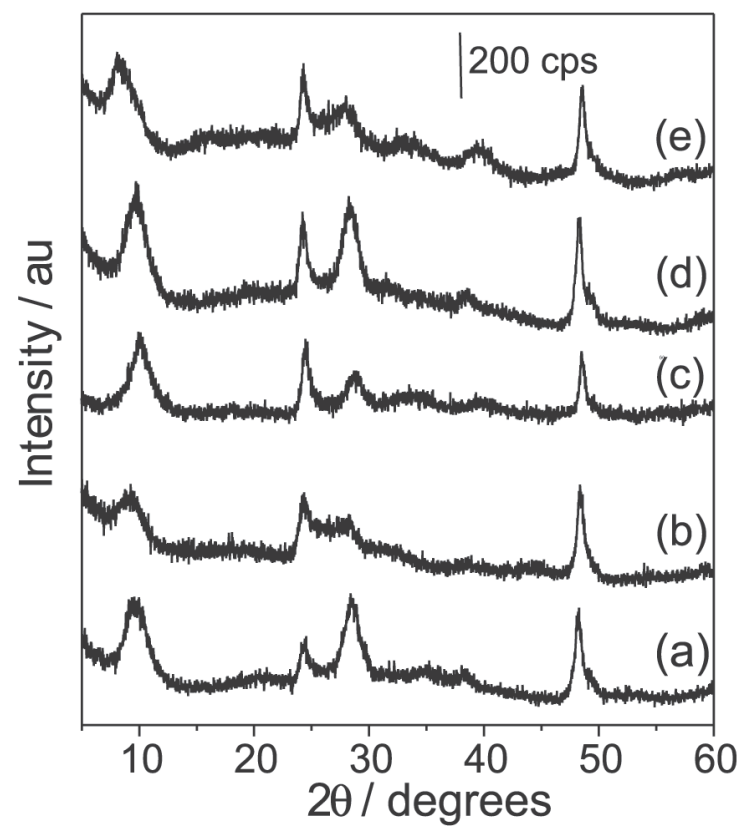

Figure 4. X-ray patterns of (a) as-prepared nanotubes $\left(\mathrm{NTTiO}_{x}\right)$ and ion exchanged nanotubes: (b) $\mathrm{H}^{+}\left(\mathrm{H}-\mathrm{NTTiO}_{\mathrm{x}}\right),(\mathrm{c}) \mathrm{Cu}^{2+}\left(\mathrm{Cu}-\mathrm{NTTiO}_{\mathrm{x}}\right)$, (d) $\mathrm{Ca}^{2+}$ $\left(\mathrm{Ca}-\mathrm{NTTiO}_{\mathrm{x}}\right)$ and $(\mathrm{e}) \mathrm{Co}^{2+}\left(\mathrm{Co}-\mathrm{NTTiO}_{\mathrm{x}}\right)$.

We also studied the ion exchanged samples with FTIR (see Figures 5A and 5B ). In the 4000-1300 $\mathrm{cm}^{-1}$ spectral region (Figure 5A), the FTIR spectra of both as-prepared and modified titanate nanotubes are similar, being characterized by a broad and intense band located at about $3290 \mathrm{~cm}^{-1}$ that can be attributed to O-H stretching mode. The presence of this peak indicates the presence of surface hydroxyl groups and water molecules adsorbed in the surface and in the interlayer space. The profile of this band also suggests a complex hydrogen bond environment. The presence of water molecules in all samples is confirmed by the presence of the $1630 \mathrm{~cm}^{-1}$ peak that is assigned to the H-O-H deformation mode $\left(\delta_{\mathrm{H}-\mathrm{O}-\mathrm{H}}\right)$.

In the $1250-250 \mathrm{~cm}^{-1}$ spectral region (Figure $5 \mathrm{~B}$ ), the FTIR spectra of the as-prepared $\mathrm{NTTiO}_{x}$ are different from those of modified $\mathrm{NTTiO}_{\mathrm{x}}$. The former is characterized by bands at 897, 470, $287 \mathrm{~cm}^{-1}$ and shoulders at 520 and 340 $\mathrm{cm}^{-1}$. The FTIR spectrum of bulk $\mathrm{Na}_{2} \mathrm{Ti}_{3} \mathrm{O}_{7}$ presents more and sharper bands than the spectrum of the $\mathrm{NTTiO}_{x} \cdot{ }^{34}$ However, nanotube spectrum exhibits broad bands very close in energy to those of bulk $\mathrm{Na}_{2} \mathrm{Ti}_{3} \mathrm{O}_{7}$, except for the intense band at $730 \mathrm{~cm}^{-1} .{ }^{34}$ Such differences may be attributed to the diameter of few nanometers and tubular morphology. The band at $897 \mathrm{~cm}^{-1}$ is attributed to the Ti-O stretching modes involving non-bridging oxygen atoms, which are interacting with $\mathrm{Na}^{+}$ions..$^{20,25,35}$ This Ti-O bond would be a kind of terminal bond sticking out from the walls that can then directly interact with the cations. The band near $470 \mathrm{~cm}^{-1}$ is attributed to the Ti-O-Ti vibrations of the interconnected octahedra that are the rigid units responsible for the formation of the walls. The mode at $287 \mathrm{~cm}^{-1}$ is assigned to vibrations involving Ti-O-A (A is the interlayer cation) as identified in Raman spectroscopic studies of titanium oxide nanotubes. ${ }^{20,25,36}$ The band assignments in the $1250-250 \mathrm{~cm}^{-1}$ spectral region (Figure 5B) for the $\mathrm{NTTiO}_{x}$ sample are further supported when we analyze the modified samples. The bands more affected in the modified samples are those related to Ti-O-A. The band at $897 \mathrm{~cm}^{-1}$ changed to $920,900,880$ and $916 \mathrm{~cm}^{-1}$ for H$\mathrm{NTTiO}_{x}, \mathrm{Cu}-\mathrm{NTTiO}_{x}, \mathrm{Ca}-\mathrm{NTTiO}_{x}$ and Co-NTTiO , respectively. The band at $287 \mathrm{~cm}^{-1}$ changed to 268,300 , 281, 279 for H- $\mathrm{NTTiO}_{x}, \mathrm{Cu}-\mathrm{NTTiO}_{x}, \mathrm{Ca}-\mathrm{NTTiO}_{x}$ and Co$\mathrm{NTTiO}_{x}$, respectively. On the other hand, the band at 470 $\mathrm{cm}^{-1}$ only broadened slightly. Again, the results indicate that the exchanged cation are in the interlayer region since the more affected bands are those assigned to motions involving the A cation. The presence of exchanged cation in the interlayer space strongly suggests that the tube walls are formed by a titanate. Also, the presence of exchanged cations confirms the potentiality of exchange reaction as a route for chemically modifying the titanate nanotubes. Therefore, from the FTIR spectra we could infer that titanate nanotubes have chemical bonds of the following nature: surface $\mathrm{Ti}-\mathrm{OH}$, Ti-O-Ti bonds interconnecting the octahedral network, Ti-O-A and Ti-O terminal bonds. 

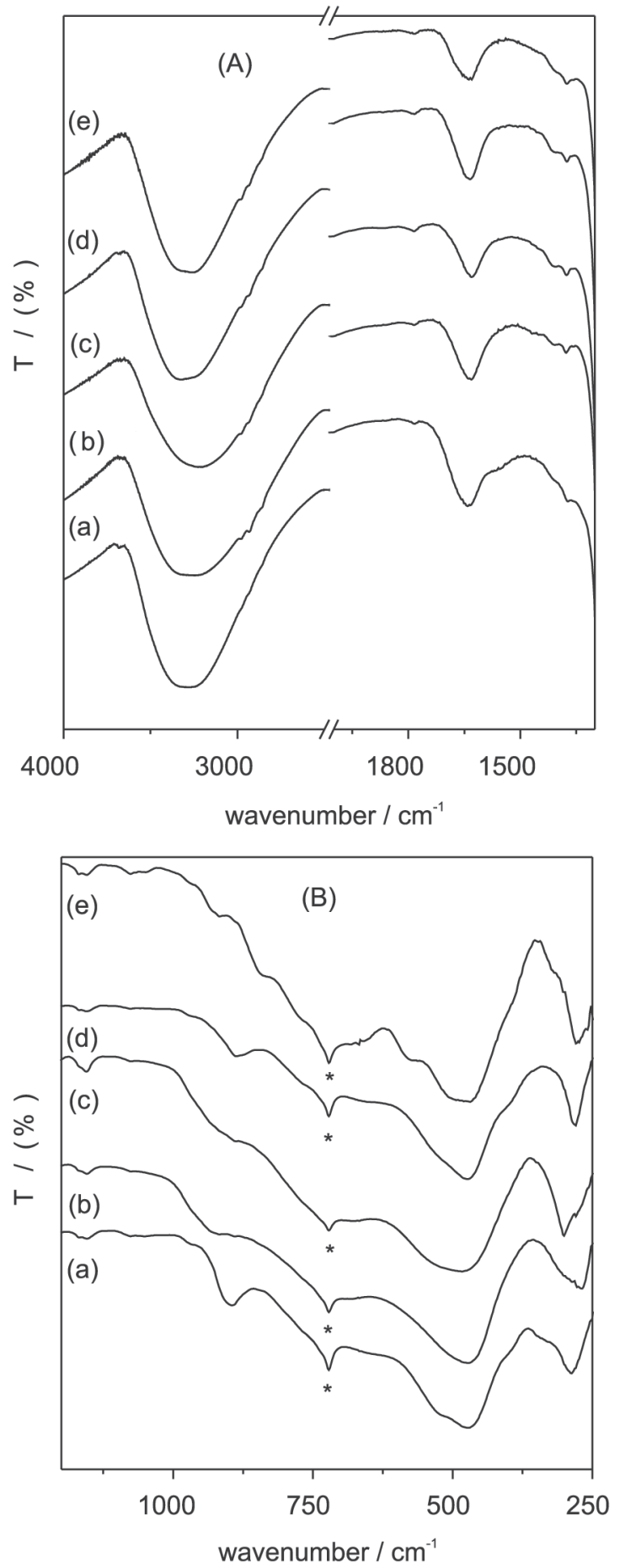

Figure 5. FTIR spectra in the region of (A) $4000-1300 \mathrm{~cm}^{-1}$ and (B) 1250$250 \mathrm{~cm}^{-1}$ for (a) $\mathrm{NTTiO}_{x}$, (b) $\mathrm{H}-\mathrm{NTTiO}_{x}$, (c) Cu-NTTiO ${ }_{x}$, (d) Ca-NTTiO and (e) Co-NTTiO . (*) Nujol.

\section{Thermal decomposition of titanate nanotubes}

In order to further investigate and support the composition and structure proposed in the previous sections for the nanotubes we studied the thermal decomposition of $\mathrm{NTTiO}_{x}$ (nanotubes washed with deionized water) and
$\mathrm{H}_{-\mathrm{NTTiO}}$ (nanotubes submitted to exchange reactions with $\mathrm{H}^{+}$). The analysis of the thermally treated samples also allows evaluating the structure and the morphologic relationship of the decomposition products.

The TGA scans are characterized by a continuous mass loss from room temperature up to $600{ }^{\circ} \mathrm{C}$ (Figures 6a and $6 b)$.
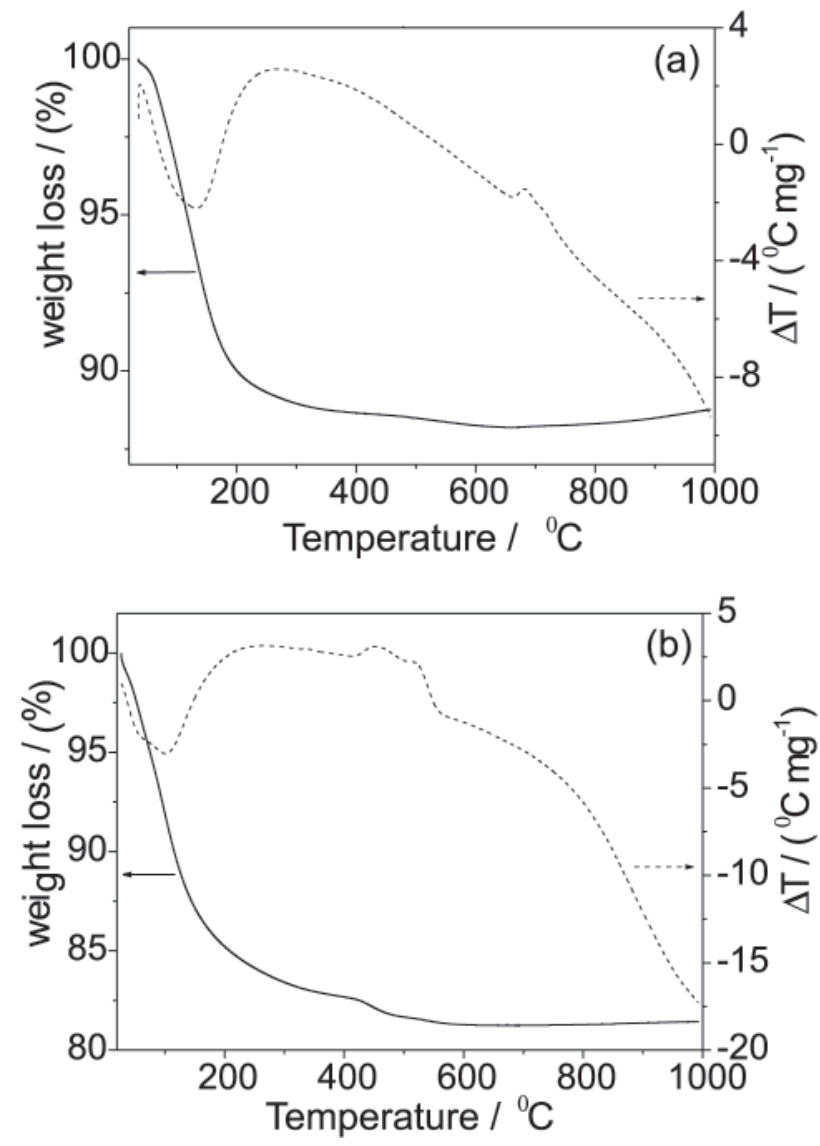

Figure 6. (-) TGA and (---) DTA curves for (a) as-prepared $\left(\mathrm{NTTiO}_{\mathrm{x}}\right)$ and (b) $\mathrm{H}$-exchanged titanate nanotubes $\left(\mathrm{H}-\mathrm{NTTiO}_{\mathrm{x}}\right)$.

For the $\mathrm{NTTiO}_{x}$ sample, the endothermic peak from 25 to $250{ }^{\circ} \mathrm{C}$ in the DTA curve (Figure 6a) presents a shoulder at about $105{ }^{\circ} \mathrm{C}$ and a minimum at about $130{ }^{\circ} \mathrm{C}$. The mass loss observed in the TGA scan (Figure 6a) for this temperature range was $10.7 \%$ from the initial mass. Such thermal events would be associated with the releasing of adsorbed and interlayer water. An in situ $\mathrm{X}$-ray diffractogram measured at $250{ }^{\circ} \mathrm{C}$ (Figure 7a) exhibits some differences when compared with the asprepared sample. The peak near $2 \theta \sim 10^{\circ}$ is shifted toward higher angle values thus indicating a decrease in the interlayer distance for this plane. The contraction in the interlayer space was calculated as being $1.70 \AA$ and is consistent with the release of water molecules present in interlayer region. This result is very important in the sense that the $2 \theta \sim 10^{\circ}$ is associated with the interlayer 
spacing and that these nanoparticles exhibits features of layered compounds. The remaining diffraction peaks are slightly modified thus suggesting that the atomic structure is preserved in the temperature range from 25 to $250{ }^{\circ} \mathrm{C}$.

In the $250-500{ }^{\circ} \mathrm{C}$ temperature range, the $\mathrm{NTTiO}_{x}$ sample exhibits in the TGA scan (Figure 6a) a mass loss of about $1 \%$. This loss is associated with the release of hydroxyl groups adsorbed on the surface of the nanotubes. The X-ray patterns in this temperature range (Figure 7a) present only slight changes. We can observe a small variation in the relative intensity of the peak, thus indicating that the titanate structure is preserved up to $500{ }^{\circ} \mathrm{C}$. The TEM image of the $\mathrm{NTTiO}_{x}$ sample treated at $400{ }^{\circ} \mathrm{C}$ for $1 \mathrm{~h}$ (see Figure 8a) confirms that the tubular morphology is also preserved.

In the $500-600{ }^{\circ} \mathrm{C}$ temperature range, the TGA scan (Figure 6a) shows that almost no mass loss $(\sim 0.1 \%)$ occurs. On the other hand, the X-ray pattern at $600{ }^{\circ} \mathrm{C}$ exhibits new peaks, superimposed onto the pattern of the tubular structure (peaks marked with $\mathbf{o}$ in Figure 7a). These new peaks could be assigned to the $\mathrm{Na}_{2} \mathrm{Ti}_{6} \mathrm{O}_{13}$ compound.

The formation of a $\mathrm{Na}_{2} \mathrm{Ti}_{6} \mathrm{O}_{13}$ phase in the decomposition process plays an important role in understanding the structural properties of the titanate nanotube. We have proposed that the structure of the as-prepared $\mathrm{NTTiO}_{x}$ is very close to the $\mathrm{Na}_{2} \mathrm{Ti}_{3} \mathrm{O}_{7}$ phase. The structural difference between $\mathrm{Na}_{2} \mathrm{Ti}_{3} \mathrm{O}_{7}$ and $\mathrm{Na}_{2} \mathrm{Ti}_{6} \mathrm{O}_{13}$ is that the former presents a lamellar structure with $\mathrm{Ti}_{3} \mathrm{O}_{7}{ }^{2-}$ corrugated layers (steps formed by the connections among three $\mathrm{TiO}_{6}$ octahedron) and two interlamellar $\mathrm{Na}^{+}$ions, ${ }^{26}$ while the latter exhibits a tunnellike structure with two $\mathrm{Na}^{+}$ions inside the tunnel. From the structural point of view, the tunnels of the $\mathrm{Na}_{2} \mathrm{Ti}_{6} \mathrm{O}_{13}$ phase can be formed from lamellar $\mathrm{Na}_{2} \mathrm{Ti}_{3} \mathrm{O}_{7}$ by connection of $\mathrm{Ti}_{3} \mathrm{O}_{7}^{2-}$ units of adjacent layers, keeping the two $\mathrm{Na}^{+}$ions inside the tunnel..$^{34}$ The details of these structures can be seen in the Figure 1 of reference 29. Sauvet et al. ${ }^{37}$ reported a study in which bulk $\mathrm{Na}_{2} \mathrm{Ti}_{3} \mathrm{O}_{7}$, under heating at $1100{ }^{\circ} \mathrm{C}$, can be converted by a "dimerization-like" process into $\mathrm{Na}_{2} \mathrm{Ti}_{6} \mathrm{O}_{13}$. The presence of $\mathrm{Na}_{2} \mathrm{Ti}_{6} \mathrm{O}_{13}$ in the decomposition products provides strong evidence that the structure and composition of the as-prepared $\mathrm{NTTiO}_{x}$ is very close to $\mathrm{Na}_{2} \mathrm{Ti}_{3} \mathrm{O}_{7}$. However, a TEM image of the $\mathrm{NTTiO}_{x}$ sample thermally treated at $600{ }^{\circ} \mathrm{C}$ for $1 \mathrm{~h}$ indicated the presence of nanorods rather than nanotubes (Figure 8b). This means that the $\mathrm{Na}_{2} \mathrm{Ti}_{3} \mathrm{O}_{7}$ phase plays a key role in stabilizing the tubular morphology. The nanorods observed in the TEM images present similar diameters (average of $9.0 \mathrm{~nm}$ ) to the precursor nanotubes.

Further increasing the thermal treatment temperature to $650{ }^{\circ} \mathrm{C}$ we observed in the X-ray pattern peaks related to the
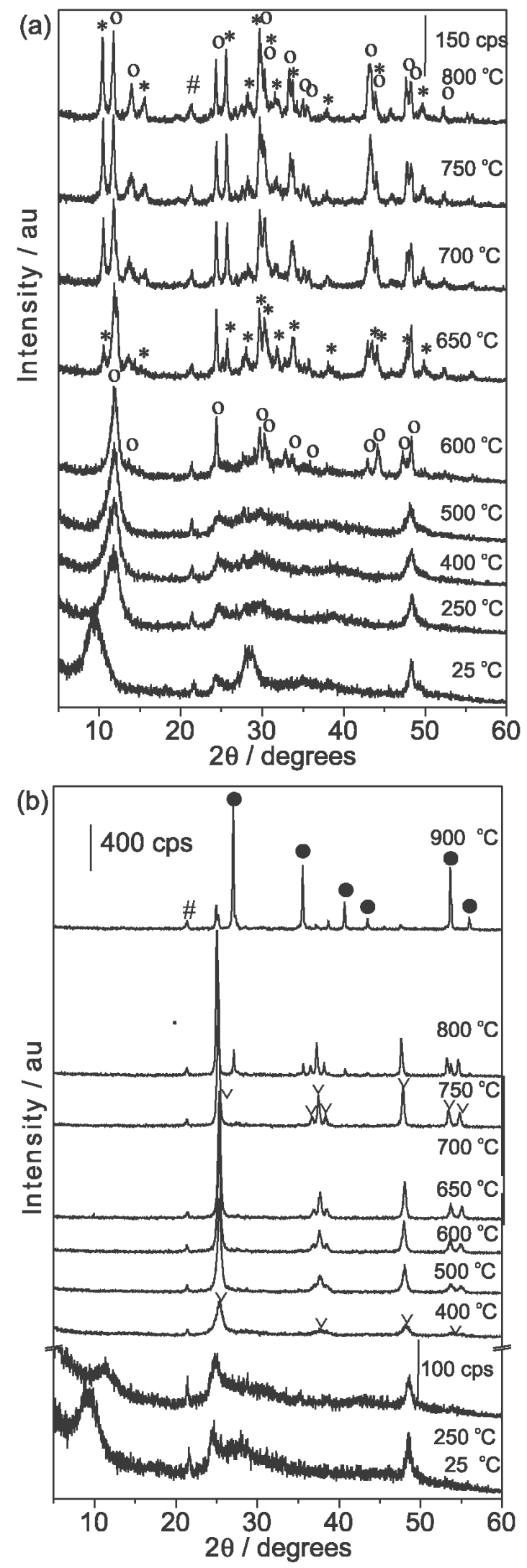

Figure 7. In situ X-ray diffraction measurements for (a) as-prepared $\left(\mathrm{NTTiO}_{\mathrm{x}}\right)$ and $(\mathrm{b}) \mathrm{H}$-exchanged titanate nanotubes $(\mathrm{H}-\mathrm{NTTiO})_{\mathrm{x}}$ ). (\#) sample holder; (o) $\mathrm{Na}_{2} \mathrm{Ti}_{6} \mathrm{O}_{13} ;\left(^{*}\right) \mathrm{Na}_{2} \mathrm{Ti}_{3} \mathrm{O}_{7} ;(v) \mathrm{TiO}_{2}$ (anatase); (•) $\mathrm{TiO}_{2}$ (rutile). 

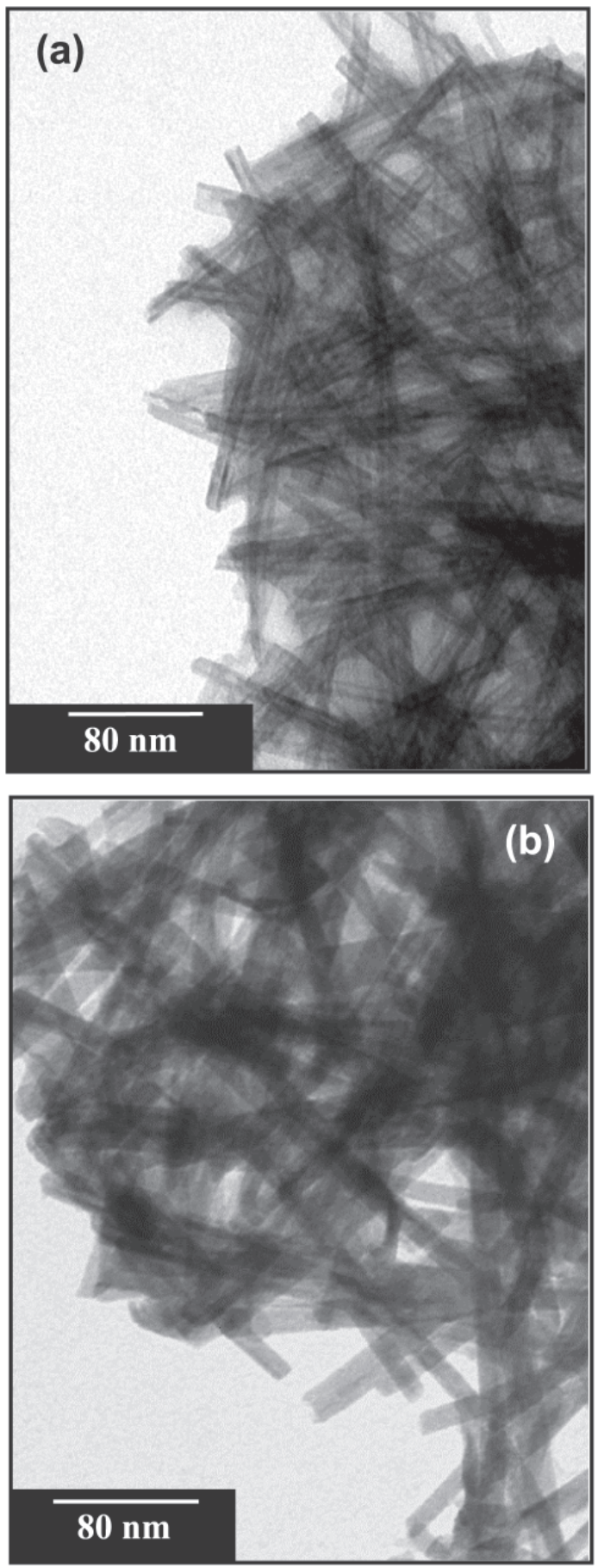

Figure 8. TEM images of $\mathrm{NTTiO}_{x}$ thermally treated at (a) 400 and (b) $600{ }^{\circ} \mathrm{C}$.

bulk $\mathrm{Na}_{2} \mathrm{Ti}_{3} \mathrm{O}_{7}$ (peaks marked with *). This result is similar to what Sauvet et al. ${ }^{37}$ observed for bulk titanate samples. They showed that the conversion of $\mathrm{Na}_{2} \mathrm{Ti}_{3} \mathrm{O}_{7}$ into $\mathrm{Na}_{2} \mathrm{Ti}_{6} \mathrm{O}_{13}$ is not complete. However, after increases in the treatment temperature the X-ray patterns did not present the formation of new phases. It should be pointed out that we have not observed any peak that could be associated with $\mathrm{TiO}_{2}$ thus indicating that the sample is mostly composed of sodium titanate. This fact is attributed to the absence of protons in the interlayer region of the $\mathrm{NTTiO}_{x}$ samples since these samples were washed with deionized water only $(\mathrm{pH} 12$ 11). The charge balance is only due to $\mathrm{Na}^{+}$ions.

For H-NTTiO the DTA curve (Figure 6b) presents an endothermic peak in the temperature range from 25 to $250{ }^{\circ} \mathrm{C}$. The TGA curve indicated a mass loss in this temperature range of $15.8 \%$ (Figure 6b). In part, this loss could be associated with the release of adsorbed and interlamellar water. The in situ X-ray patterns (Figure 7b) at $250{ }^{\circ} \mathrm{C}$ indicate that the interlayer water was released. It is clear that the $2 \theta \sim 10^{\circ}$ peak shift towards higher angles and the calculated contraction of the interlayer distance was $1.70 \AA$, similar to $\mathrm{NTTiO}_{x}$. On the other hand, the $\mathrm{X}$-ray diffractogram also shows a profile change in the $2 \theta$ $\sim 25^{\circ}$ peak. This peak slightly shifts toward higher angle values and increases in intensity, thus suggesting the presence of anatase $\mathrm{TiO}_{2}$. Thus, it is likely that in this temperature range we also have the onset of release of the interlayer protons, leading to the formation of $\mathrm{TiO}_{2}$.

The chemical formula proposed for $\mathrm{H}_{-} \mathrm{NTTiO}_{x}$ is $\mathrm{H}_{2} \mathrm{Ti}_{3} \mathrm{O}_{7} \cdot \mathrm{nH}_{2} \mathrm{O}$. The mass loss expected for the elimination of one structural water molecule from $\mathrm{H}_{2} \mathrm{Ti}_{3} \mathrm{O}_{7}$ is $7.98 \%$ following the $\mathrm{H}_{2} \mathrm{Ti}_{3} \mathrm{O}_{7} \rightarrow 3 \mathrm{TiO}_{2}+\mathrm{H}_{2} \mathrm{O}$ reaction. Thus, in the $25-250{ }^{\circ} \mathrm{C}$ temperature range the release of adsorbed and interlayer water along with structural water originating from the release of both interlayer protons and surface hydroxyls occur. In this temperature range the titanate phase and $\mathrm{TiO}_{2}$ coexist. Proton removal would explain why the mass loss in $\mathrm{H}_{-\mathrm{NTTiO}}$ is higher than that of $\mathrm{NTTiO}_{\mathrm{x}}$ for the same temperature range. TEM images (Figure 9a and inset) of $\mathrm{H}-\mathrm{NTTiO}_{x}$ thermally treated at $250{ }^{\circ} \mathrm{C}$ for $1 \mathrm{~h}$ also indicates that the tubular morphology was preserved with the onset of $\mathrm{H}_{2} \mathrm{Ti}_{3} \mathrm{O}_{7}$ decomposition.

By further increasing the temperature to $400{ }^{\circ} \mathrm{C}$ (Figure $7 \mathrm{~b}$ ), all the observed peaks can be indexed to the anatase $\mathrm{TiO}_{2}$ phase. The TGA scan (Figure 6b) shows a mass loss of only $1.4 \%$ in the $250-400{ }^{\circ} \mathrm{C}$ temperature range. Such a mass loss is small account for the formation of $\mathrm{TiO}_{2}$ in this temperature range, thus indicating that, as in the previous thermal event, water removal as depicted in the reaction outlined above has also occurred, by adding the mass loss for these two temperature ranges, we have $17.2 \%$ of the initial mass. Considering that $7.98 \%$ comes from the release of structural water during the formation of $\mathrm{TiO}_{2}$, we have that $9.2 \%$ (17.2-7.98) is attributed to adsorbed and interlayer water. Such a value is close to that observed for $\mathrm{NTTiO}_{\mathrm{x}}$ sample.

In order to check the morphology changes after phase transformation, we have performed TEM images of $\mathrm{H}-\mathrm{NTTiO}_{\mathrm{x}}$ samples thermally treated at $400{ }^{\circ} \mathrm{C}$ for $1 \mathrm{~h}$ 

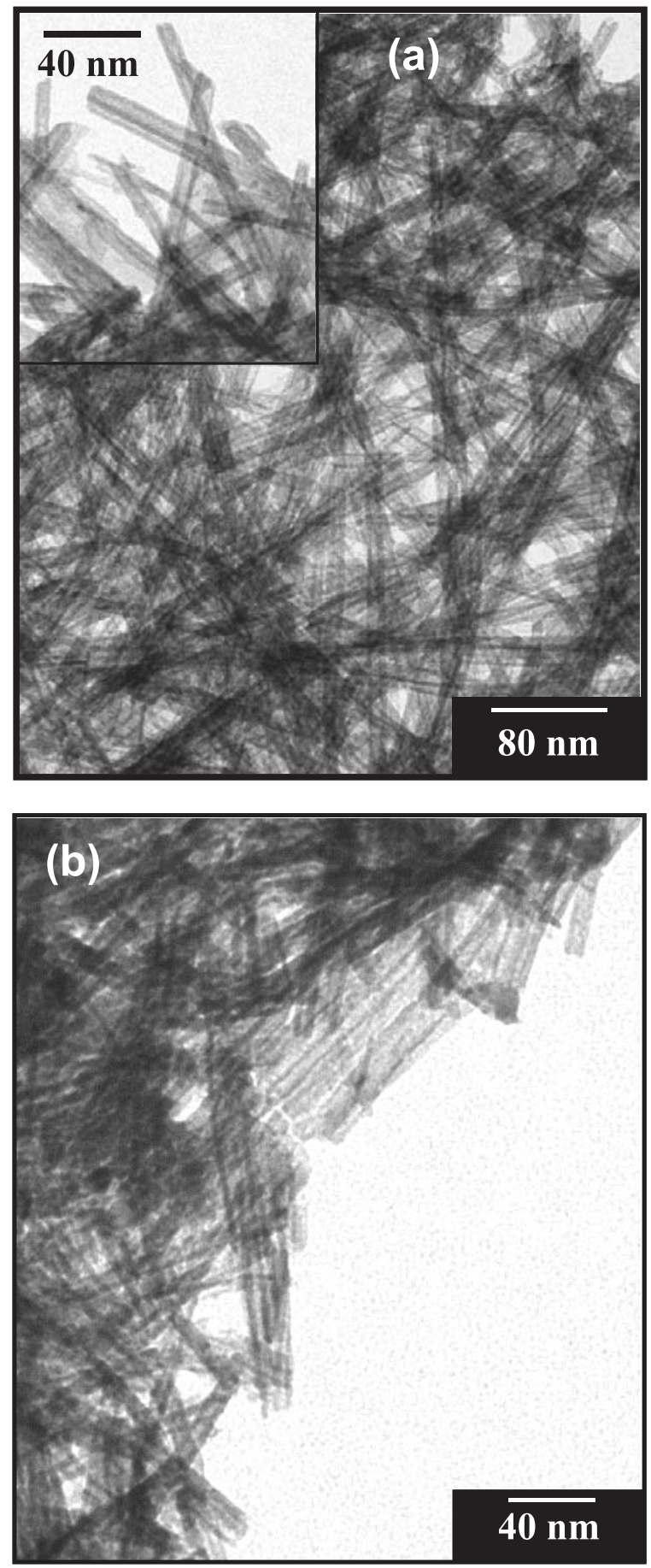

Figure 9. TEM images of the $\mathrm{H}$-exchanged titanates nanotubes $\left(\mathrm{H}-\mathrm{NTTiO}_{\mathrm{x}}\right.$ ) thermally treated at (a) 250 and (b) $400{ }^{\circ} \mathrm{C}$.

(Figure 9b). The TEM images indicate the presence of nanotubes, although their walls are slightly damaged.

The X-ray pattern in the $400-750{ }^{\circ} \mathrm{C}$ temperature range for the H-NTTiO sample exhibits an intensification of the peaks associated with anatase $\mathrm{TiO}_{2}$ (Figure 7b). The mass loss observed in the TGA curve (Figure 6a) was $1.4 \%$ and could be associated with the release of remaining structural water. By further increasing the temperature, we observe the onset of the anatase to rutile phase transformation between 750 and $800{ }^{\circ} \mathrm{C}$ (Figure 7b).

Finally, the thermal behavior of $\mathrm{NTTiO}_{x}$ and $\mathrm{H}_{-} \mathrm{NTTiO}_{\mathrm{x}}$ samples supports our proposal for the structure and composition of the titanate nanotubes prepared by the Kasuga method. The thermal evolution of the as-prepared nanotube samples $\left(\mathrm{NTTiO}_{\mathrm{x}}\right)$ indicate the presence sodium titanate phases only. The formation of these phases suggests that the $\mathrm{Na}^{+}$ions belong to the atomic structure of the tube walls. In the thermal decomposition of $\mathrm{H}_{-} \mathrm{NTTiO}_{\mathrm{x}}$ samples we have observed, from in situ X-ray measurements, the formation of $\mathrm{TiO}_{2}$ only without any evidence for sodium titanate phases. The formation of $\mathrm{TiO}_{2}$ during the thermal treatment of $\mathrm{H}-\mathrm{NTTiO}_{x}$ samples indicates that the sodium was totally exchanged by protons. The data strongly support a chemical formula of the titanate nanotubes as $\mathrm{Na}_{2-x} \mathrm{H}_{x} \mathrm{Ti}_{3} \mathrm{O}_{7} \cdot \mathrm{nH}_{2} \mathrm{O}, 0 \leq x \leq 2$. The $\mathrm{x}$ value depends on the washing conditions: $(i)$ for the samples washed with deionized water until $\mathrm{pH} 11-12\left(\mathrm{NTTiO}_{\mathrm{x}}\right), x$ and $n$ would be approximately 0 and 2, respectively. The $n$ value was determined based on the TGA curves (Figure 6a). The composition of these nanotubes would be $\mathrm{Na}_{2} \mathrm{Ti}_{3} \mathrm{O}_{7} \cdot 2 \mathrm{H}_{2} \mathrm{O}$ (we have not accounted for the surface hydroxyl groups); (ii) for the samples treated with $0.1 \mathrm{~mol} \mathrm{~L}^{-1} \mathrm{HCl}$ for $24 \mathrm{~h}$, the $x$ and $n$ values would is 2 and 1.5 , respectively, the composition being $\mathrm{H}_{2} \mathrm{Ti}_{3} \mathrm{O}_{7} \cdot 1.5 \mathrm{H}_{2} \mathrm{O}$.

\section{Conclusions}

In this work we report the ion exchange and thermal treatment of titanium oxide nanotubes prepared by Kasuga's method. Based in these results we proposed a new composition for the as-prepared nanotubes: $\mathrm{Na}_{2} \mathrm{Ti}_{3} \mathrm{O}_{7} \cdot \mathrm{nH}_{2} \mathrm{O}$. The structure of the nanotube walls is similar to that found in layered bulk $\mathrm{Na}_{2} \mathrm{Ti}_{3} \mathrm{O}_{7}$. If nanotubes are washing with acid solution, the $\mathrm{Na}^{+}$can be exchanged by $\mathrm{H}^{+}$, and a general chemical formula was proposed: $\mathrm{Na}_{2-\mathrm{x}} \mathrm{H}_{\mathrm{x}} \mathrm{Ti}_{3} \mathrm{O}_{7} \cdot \mathrm{nH}_{2} \mathrm{O}, 0 \leq x \leq 2$.

The proposal of layered titanate was supported by the ion exchange reactions, where it was possible to exchange the $\mathrm{Na}^{+}$ions by $\mathrm{H}^{+}, \mathrm{Ca}^{2+}, \mathrm{Cu}^{2+}$ and $\mathrm{Co}^{2+}$. Furthermore, the exchange reactions would be an option for chemically modifying these nanotubes. Additionally, the analysis of the products of thermal decomposition allowed us to get information about the composition and structure of the as-prepared nanotubes. For $\mathrm{x}=0$ (as-prepared nanotubes), the tubular structure is preserved up to $500{ }^{\circ} \mathrm{C}$. Increasing the temperature to $600{ }^{\circ} \mathrm{C}$, the products of thermal decomposition are $\mathrm{Na}_{2} \mathrm{Ti}_{6} \mathrm{O}_{13}$ and $\mathrm{Na}_{2} \mathrm{Ti}_{3} \mathrm{O}_{7}$. The $\mathrm{Na}_{2} \mathrm{Ti}_{6} \mathrm{O}_{13}$ exhibits an atomic structure with channels originating from 
the layered compound $\mathrm{Na}_{2} \mathrm{Ti}_{3} \mathrm{O}_{7}$ by the connection of $\mathrm{Ti}_{3} \mathrm{O}_{7}{ }^{2-}$ units of neighboring layers. When $\mathrm{Na}_{2} \mathrm{Ti}_{6} \mathrm{O}_{13}$ is formed the nanotubes are converted into nanorods, although the conversion is not complete. On the another hand, when the nanotubes have $\mathrm{x}=2$ (obtained by the ion exchange of $\mathrm{Na}^{+}$by $\left.\mathrm{H}^{+}, \mathrm{H}_{2} \mathrm{Ti}_{3} \mathrm{O}_{7} \cdot \mathrm{nH}_{2} \mathrm{O}\right)$ the thermally treated final product is only $\mathrm{TiO}_{2}$. In this case, the anatase phase is formed for nanotubes treated at $400{ }^{\circ} \mathrm{C}$ where the tubular morphology is preserved.

Our proposal is that titanate nanotubes prepared by hydrothermal treatment of $\mathrm{TiO}_{2}$ and $\mathrm{NaOH}$ have sodium in the atomic structure since their thermal decomposition products are basically sodium titanates instead of $\mathrm{TiO}_{2}$. This later is obtained by heating the nanotubes for which the $\mathrm{Na}^{+}$was exchanged by $\mathrm{H}^{+}$. The presence of $\mathrm{Na}^{+}$in the interlayer space favors the stability of the nanotubes since the temperatures of the phase transformations are higher than for the nanotubes containing only $\mathrm{H}^{+}$. Finally, our work advances the understanding of structure and composition of titanate nanotubes.

\section{Acknowledgments}

The authors acknowledge CNPq for financial support. A.G.S.F. acknowledges financial support from $\mathrm{CNPq}$ through a research fellowship (Grant 307417/2004-2). The authors are indebted to Dr. Carlos A. P. Leite for assistance with the TEM images. This is a contribution of Millennium Institute of Complex Materials (PADCT/MCT).

\section{References}

1. Iijima, S.; Nature 1991, 354, 56.

2. Tenne, R.; Rao, C. N. R.; Phil. Trans. R. Soc. Lond. A 2004, 362, 2099.

3. Remskar, M.; Adv. Mater. 2004, 16, 1497.

4. Tenne, R.; Colloid Surface A 2002, 208, 83.

5. Tenne, R.; Homyonfer, M.; Feldman, Y.; Chem. Mater. 1998, 10,3225 .

6. Idakiev, V.; Yuan, Z. Y.; Tabakova, T.; Su, B. L.; Appl. Catal. A 2005, 281, 149.

7. Li, J.; Tang, Z.; Zhang, Z.; Electrochem. Commun. 2005, 7, 62.

8. Kasuga, T.; Hiramatsu, M.; Hoson, A.; Sekino, T.; Niihara, K.; Langmuir 1998, 14, 3160.

9. Wang, Y. Q.; Hu, G. Q.; Duan, X. F.; Sun, H. L.; Xue, Q. K.; Chem. Phys. Lett. 2002, 365, 427.

10. Yao, B. D.; Chan, Y. F.; Zhang, X. Y.; Zhang, W. F.; Yang, Z. Y.; Wang, N.; Appl. Phys. Lett. 2003, 82, 281.

11. Zhang, S.; Peng, L. M.; Chen, Q.; Du, G. H.; Dawson, G.; Zhou, W. Z.; Phys. Rev. Lett. 2003, 91, 256103.

12. Bavykin, D. V.; Parmon, V. N.; Lapkin, A. A.; Walsh, F. C.; J. Mater. Chem. 2004, 14, 3370.
13. Zhang, S.; Chen, Q.; Peng, L. M.; Phys. Rev. B 2005, 71, 014104.

14. Niederberger, M.; Muhr, H. J.; Krumeich, F.; Bieri, F.; Günther, D.; Nesper, R.; Chem. Mater. 2000, 12, 1995.

15. Wei, M. D.; Konishi, Y.; Zhou, H. S.; Sugihara, H.; Arakawa, H.; Chem. Phys. Lett. 2004, 400, 231.

16. Ferreira, O. P.; Otubo, L.; Romano, R.; Alves, O. L.; Cryst. Growth Des. 2006, 6, 601.

17. Du, G. H.; Chen, Q.; Che, R. C.; Yuan, Z. Y.; Peng, L. M.; Appl. Phys. Lett. 2001, 79, 22.

18. Chen, Q.; Du, G. H.; Zhang, S.; Peng, L. M.; Acta Cryst. B 2002, 58, 587 .

19. Suzuki, Y.; Yoshikawa, S.; J. Mater. Res. 2004, 19, 982.

20. Sun, X.; Li, Y.; Chem. Eur. J. 2003, 9, 2229.

21. Yang, J.; Jin, Z.; Wang, X.; Li, W.; Zhang, J.; Zhang, S.; Guo, X.; Zhang, Z.; Dalton Trans. 2003, 20, 3898.

22. Ma, R.; Bando, Y.; Sasaki, T.; Chem. Phys. Lett. 2003, 380, 577.

23 Ma, R.; Fukuda, K.; Sasaki, T.; Osada, M.; Bando, Y.; J. Phys. Chem. B 2005, 109, 6210.

24. Tsai, C. C.; Teng, H.; Chem. Mater. 2006, 18, 367.

25. Kasuga, T.; Hiramatsu, M.; Hoson, A.; Sekino, T.; Niihara, K.; Adv. Mater. 1999, 11, 1307

26. Yakubovich, O. V.; Kireev, V. V.; Crystallogr. Rep. 2003, 48, 24.

27. Souza Filho, A. G.; Ferreira, O. P.; Santos, E. J. G.; Mendes Filho, J.; Alves, O. L.; Nano Lett. 2004, 4, 2099.

28. Cao, J.; Choi, J.; Musfeidt, J. L.; Lutta, S.; Whittingham, M. S.; Chem. Mater. 2004, 14, 731.

29. Papp, S.; Korosi, L.; Meynen, V.; Cool, P.; Vansant, E. F.; Dekany, I.; J. Solid State Chem. 2005, 178, 1664.

30. Cardoso, V. D.; de Souza, A. G.; Sartorattob, P. P. C.; Nunes, L. M.; Colloid Surface A 2004, 248, 145.

31. Yang, J.; Li, D.; Wang, X.; Yang, X. J.; Lu, L.; J. Mater. Sci. 2003, 38, 2907.

32. Niyogi, S.; Hamon, M. A.; Hu, H.; Zhao, B.; Bhowmik, P.; Sen, R.; Itkis, M. E.; Haddon. R. C.; Acc. Chem. Res. 2002, 35, 1105.

33. Ma, R. Z.; Sasaki, T.; Bando, Y.; Chem. Commun. 2005, 7, 948.

34. Peng, G. W.; Liu, H. S.; Mater. Chem. Phys. 1995, 42, 264.

35. Kim, H. M.; Miyaji, F.; Kokubo, T.; Nakamura, T.; J. Mater. Sci Mater. Med. 1997, 8, 341.

36. Hodos, M.; Horváth, E.; Haspel, H.; Kukovecz, A.; Kónya, Z.; Kiricsi, I.; Chem. Phys. Lett. 2004, 399, 512.

37. Sauvet, A. L.; Baliteau, S.; Lopez, C.; Fabry, P.; J. Solid. State Chem. 2004, 177, 4508 .

Received: February 9, 2006

Published on the web: March 13, 2006

FAPESP helped in meeting the publication costs of this article. 